\title{
An overview of applications in pineapple agroindustrial residues
}

\author{
Franklyn da Cruz LIMA ${ }^{1}$, Andressa Juliana Almeida SIMÕES ${ }^{1}$, Isabela Maria Monteiro VIEIRA ${ }^{1,2}$, Daniel Pereira \\ SILVA $^{1,2^{*}}$, Denise Santos RUZENE ${ }^{1,2}$
}

Received May 13, 2018; accepted September 06, 2018.

Delo je prispelo 13. maj 2018, sprejeto 06. september 2018.

\begin{abstract}
Industrial food production causes a high amount of waste. This waste must be taken to a suitable location where it can be further processing. During industrial processing of the pineapple, about $50 \%$ of the mass of the fruit ends up being discarded becoming a residue. Researchers have studied these residues in order to add value to these by-products, to reduce disposal costs and guarantee environmental sustainability. This work investigates the development characteristics of research on agroindustrial residues of pineapple based on bibliometric methods to explore the structure of knowledge in this field over the years, according to the year of publication, periodicals, country, authors, area of knowledge, institutions, keywords, subject type, and citation analysis. In total 927 articles were found and after a careful analysis and selection of papers, 364 articles remained of which $82 \%$ were published only in the last decade. Most studies focused on agricultural and biological sciences. About 1183 authors from 50 different countries contributed to this subject, in which India has the largest number of publications. The results obtained with this study, highlighting the different uses for pineapple residues, can provide valuable information for researchers interested in the field of agroindustrial wastes.
\end{abstract}

Key words: bibliometric analysis; residues; agroindustrial wastes; pineapple; waste management

\section{IZVLEČEK}

\section{PREGLED UPORABE AGROINDUSTRIJSKIH OSTANKOV ANANASA}

Industrijska proizvodnja hrane povzroča velike količine odpadkov. Odpadki morajo biti spravljeni na primernem mestu, kjer so lahko nadalje obdelani. Med industrijsko predelavo ananasa postane okrog $50 \%$ mase odpadek. Ti ostanki so bili preučevani $\mathrm{z}$ vidika, da bi tem stranskim produktom dodali vrednost, zmanjšali stroške odvoza in zagotovili okoljsko vzdržnost. Prispevek preučuje razvojne značilnosti raziskav, ki se ukvarjajo s preučevanjem agroindustrijskih ostankov ananasa na osnovi bibliometričnih metod $\mathrm{z}$ namenom, da se prikaže znanje na tem področju $\mathrm{v}$ zadnjih letih glede na leto publikacije, vrsto revij, države, avtorjev, področij znanja, institucijo, ključne besede, tem raziskav in analizo citiranja. Celokupno je bilo najdenih 927 člankov. Po skrbni analizi in izboru objav je ostalo 364 člankov, od katerih je bilo $82 \%$ objavljenih v zadnjem desetletju. Večina raziskav je bila usmerjena $\mathrm{v}$ agronomske in biološke vede. Okrog 1183 avtorjev iz 50 držav je prispevalo svoj delež, med njimi ima Indija največje število publikacij. Izsledki, dobljeni v terj raziskavi, osvetljujejo različne rabe ostankov ananasa, kar lahko prispeva pomembne informacije raziskovalcem, ki ji zanima področje agroindustrijskih odpadkov.

Ključne besede: bibliometrična anliza; ostanki; agroindustrijski odpadki; ananas; upravljanje z odpadki

\section{INTRODUCTION}

Brazil is one of the largest fruit producers in the world. In terms of total volume, pineapple is one of the most important fruit crops (FAO, 2015). The crop represents, according to data from the Brazilian Institute of
Geography and Statistics (IBGE, 2017), the third largest fruit product, being surpassed only by oranges and bananas. The total planted area of pineapple in 2016 was 100,238 hectares, of which 67,254 hectares were

1 Center for Exact Sciences and Technology, Federal University of Sergipe, São Cristóvão, Sergipe, Brazil. *Corresponding author: silvadp@hotmail.com

2 Northeastern Biotechnology Network - RENORBIO, Federal University of Sergipe, São Cristóvão, Sergipe, Brazil 
harvested. Production in this same year reached $1,734,627$ tons, obtaining an average yield of 25,792 $\mathrm{kg} \cdot \mathrm{ha}^{-1}$ (IBGE, 2017). Advantages such as geographic location, wide availability of arable land and climatic conditions favor the leading role of pineapple cultivation, ensuring jobs and contributing significantly to the national economy (Brito Neto et al., 2008; Morgado et al., 2004; Silva, 2016).

Industrial food production causes a high amount of waste, such as bagasse, husks and pulp residues of the fruits. This waste must be taken to a suitable location, which in general adds a costly procedure to the industry. In addition to the cost of treating this material, many of which are of low efficiency, there are still risks for the continuity of environmental pollution (Timofiecsyk \& Pawlowsky, 2000). Since the residues produced have great potential for reuse, together with the concern for the environment, numerous studies have been carried out with the intention of taking advantage of them (Borges et al., 2004; Ferrari et al., 2004; Zhang et al., 2007). Thus, it is possible to reduce environmental pollution, and increase sustainability, along with obtaining new products with higher added value (Pelizer et al., 2007).

During industrial processing of the pineapple, the crown and stem are cut prior to desquamation. Subsequently, the shell and core are removed, leaving only the pulp. This residue usually corresponds to about $50 \%$ of the fruit mass, representing a growing environmental problem due to microbial deterioration (Ketnawa et al., 2012). The other parts of the plant, such as the stem, roots, and leaves, are generally discarded in the field as agricultural residues, representing high waste since these components also make up the fruit (Fagundes \& Fagundes, 2010).

Numerous academic studies are being carried out with the aim of making some use of the agroindustrial residues of pineapple: protein enrichment (Alexandre et al., 2013; Navid et al., 2010; Díaz-Vela et al., 2017), vinegar manufacturing (Madurai et al., 2010; Isitua \& Ibeh, 2010), extracting bromelain (Ketnawa et al., 2012; Manosroi et al., 2014) enzyme production (Selvakumar \& Sivashanmugam, 2017), preparation of activated carbon nanosheets (Sodtipinta et al., 2017), production of cellulose nanocrystals (CN) (Santos et al., 2013), represent some types of use. These documents summarize ways of taking advantage of agroindustrial residues of pineapples plants from different perspectives, but a bibliometric approach still was not applied. Thus, no study presented a comprehensive picture of this type of exploitation due to its research restrictions.

The search for indicators to quantify scientific activity and technological knowledge has increased over the years. In Brazilian literature, for example, it was mediated by the need for the government and scientific community to have instruments to promote guidelines, incentive programs and evaluation of science and technology development in Brazil (Mugnaini et al., 2004; Allen, 1969). According to Wang et al. (2014), bibliometric is a very useful tool for mapping the literature around a research, using statistical and quantitative analyzes to demonstrate patterns of productivity of articles in a given field of research, institution or country throughout the time. The bibliometric approach has been widely used in several studies, such as the use of nanotechnology in agriculture (Stopar, 2016), the analysis of scientific production related to organic agriculture (Aleixandre et al., 2015), use of energy from biomass and its interaction with the environment (Mao et al., 2018), evaluation of the evolution of the topic of food waste (Chen et al., 2016), verification of publication trends concerning natural fibers (fiber crops or fiber plants) (Bartol \& Mackiewicz-Talarczyk, 2015), evaluation of the distribution of research related to rural tourism (Hočevar \& Bartol, 2016).

Thus, the purpose of this work was to quantitatively and qualitatively evaluate the scientific literature on the use of agroindustrial residues of pineapples using bibliometric analysis which results provide valuable information to assist researchers in selecting potential research fields, identifying suitable institutions to evolve their studies, and contacting researchers for collaboration filling existing gaps in this field of research.

\section{MATERIALS AND METHODS}

\subsection{Methods}

Initially a literature review was carried out on the Scopus database, with the international scientific production on the use of agroindustrial residues of pineapples as its guideline, opting for the search of articles as the only type of document.
In this citation database, the search was used in the section of title, abstract and keywords. The following keywords together with Boolean operators were used as search strategies, only on scientific articles: TITLEABS-KEY ((pineapple*) AND (waste* OR residue* OR bagasse* OR skin* OR crown* OR peel* OR core*)) AND (LIMIT-TO (DOCTYPE, "ar")). 
After the bibliographic review, the material was analyzed. Once all publications were identified, a preselection was made, according to the theme regarding the use of pineapple agroindustrial residue guiding the study, and previously defined inclusion and exclusion criteria. All languages of publication were considered.

The collected data were organized, coded, tabulated and submitted to statistical analysis with the Scopus base itself, and statistics/network using VOSviewer software (Van Eck \& Waltman, 2018; Van Eck \& Waltman, 2014). For the purpose of analysis, the following variables were chosen: year of publication, periodicals, country, authors, area of knowledge, institutions, keywords, type of subject and citation analysis.

\subsection{Review of documents}

After searching the Scopus database, 927 articles were found in total. Articles generally provide more original search results and more information about the authors and their affiliations, and only those documents were used in the analysis.

All articles have been evaluated by the titles, abstracts and information contained in the publication. In this phase, the documents that did not correspond specifically to the object of study were identified. This stems from the fact that the use of the keywords results in a general and broad search, covering any kind of subject that contains these questions at random. Thus, scientific documents dealing with pineapple in a general manner were excluded, such as those related to the use of parts of pineapple plant (leaf and stem), pineapple fruit quality, physico-chemical properties, pesticide residues in pineapple and peeling of the fruit.

This filtering process eliminated 563 publications, resulting in 364 articles, which were exported in CSV format for bibliometric analysis.

\subsection{Analysis tools}

In this study, the Scopus database was used. VOSviewer (Van Eck \& Waltman, 2018; Van Eck \& Waltman, 2014) was used as tool for analysis and visualization of the network.

Scopus is a global citation database covering science, technology, medicine, social sciences, arts and humanities (Elsevier, 2018). This database has a vast collection of more than 71 million records and 23,700 titles from more than 5,000 international publishers. It also has intelligent tools that allow the tracing, analysis and visualization of searches, which can be done by title of the article, abstract, keywords, authors, affiliation, language, ISSN, DOI, among others (Elsevier, 2018).

VOSviewer is a software used for the creation, visualization and investigation of bibliometric maps from network data using the VOS (Visualization of Similarities) mapping technique. It is possible to use file data from databases such as Web of Science, Scopus, RIS, PubMed, Crossref JSON to build networks. It is worth noting that VOSviewer is not only restricted to the analysis of bibliometric networks, it is possible to expand its use for the elaboration, visualization and analysis of maps made up of any type of network data.

Different publications report applications of VOSviewer, such as in the importance of climate change for the production of tea (verification of the Camellia sinensis (L.) Kuntze) (Marx et al., 2017), in the analysis of the research landscape of precision agriculture in Italy (Costa et al., 2017), in the review of publications dealing with climate change and viticulture (Marx et al., 2017), in the verification of publications related to nanocellulose (Milanez et al., 2016). 


\section{RESULTS AND DISCUSSION}

\subsection{Publication trend}

The trend of publication related to the use of agroindustrial residues of pineapples is shown in Figure 1.

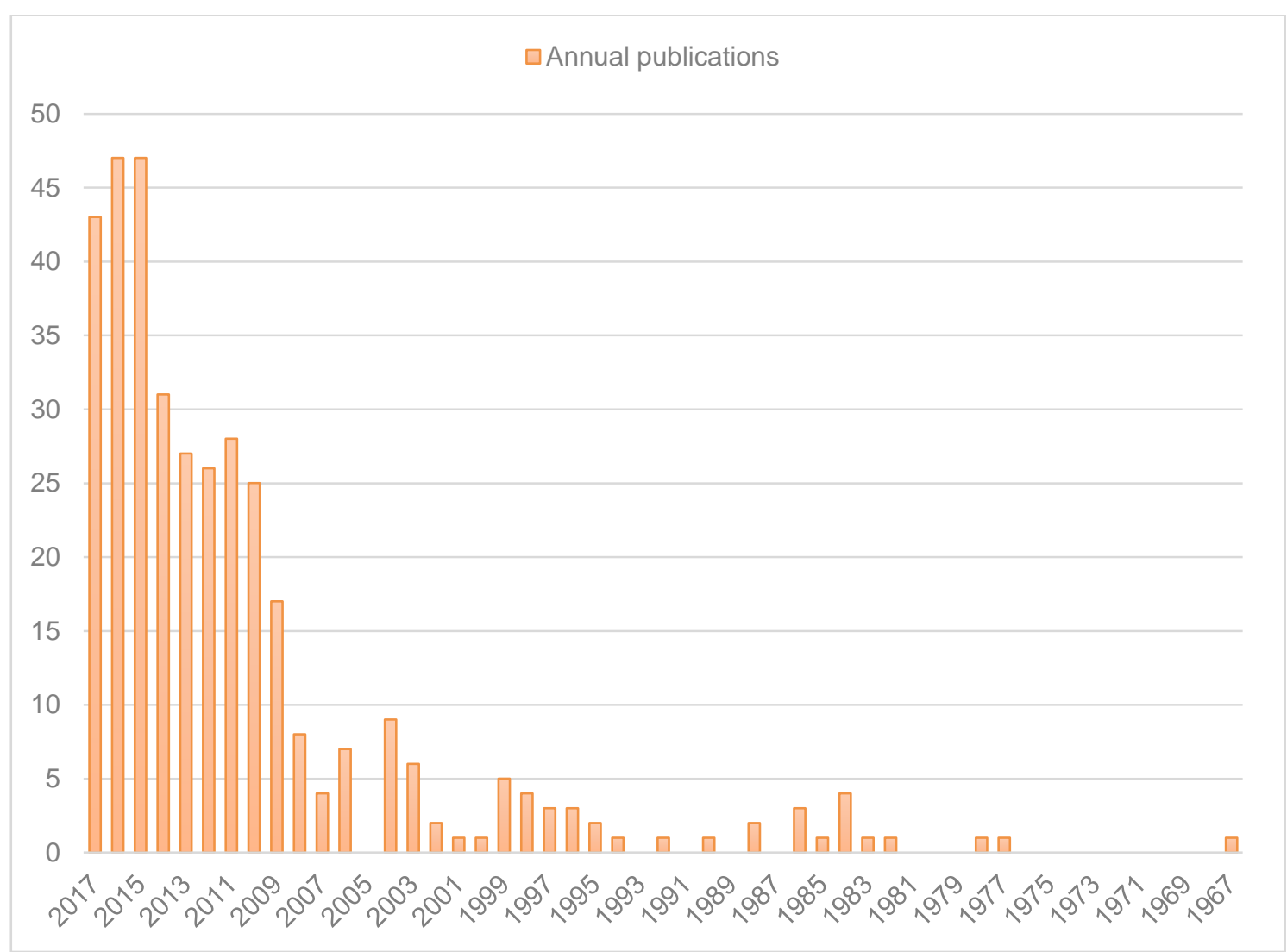

Figure 1: Trends of publications

The first publication occurred in 1967 with the work of Richardson (1967) dealing with the production of vinegar. During 1967-2007, there were few publications, followed by an increase in 2008. Publications in the last 10 years (299) represent more than $82 \%$ of the total. It should be noted that the study in question did not cover all the publications made in the year 2017, since when the research was carried out, publication data for 2017 were not complete. Thus, the observation of the results allows inferring that the annual publications have presented an increasing and constant trend during the last decade. This result can be explained by growing global concern about environmental issues, aiming at sustainable production.

\subsection{Areas of activity}

The studies that contributed to this research theme involved 21 different academic areas, as shown in Figure 2. 


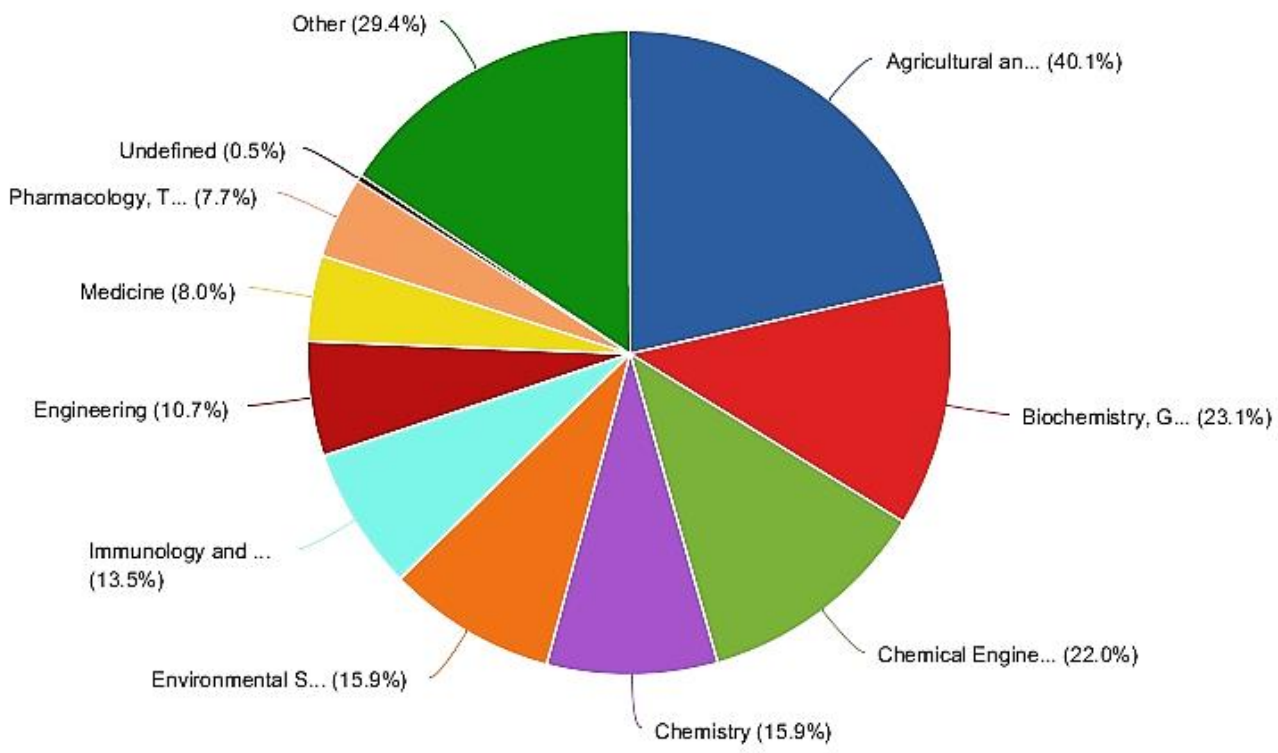

Figure 2: Areas involved in research

Among the areas (Figure 2), agricultural and biological sciences are highlighted as number 1 , with 146 publications $(40.1 \%)$, followed by biochemistry and genetics $(23.1 \%)$ and chemical engineering $(22.0 \%)$. Publications involved in environmental sciences, chemistry, immunology, engineering, medicine and pharmacology also contributed to the development of the theme of agroindustrial residues of pineapple, while other areas contributed to the remaining $29.4 \%$.

\subsection{Journals}

The 364 articles selected were published in 158 different journals, but most of these journals $(55.7 \%)$ published only one article related to the use of agroindustrial residues of pineapples. Table 1 lists the top ten journals with the largest number of publications. In general, citation times for an article might reflect its influence, though the wrong citations might occur. Thus, total citations (TC) and the average number of citations per document of a journal (TC/P) in the period are also shown in Table 1.

Table 1: Periodicals with more publications

\begin{tabular}{lllllc}
\hline$\#$ & Periodic & Publications & \% & TC $^{\mathrm{a}}$ & TC/P $^{\mathrm{b}}$ \\
\hline 1 & Bioresource Technology & 13 & 3.57 & 457 & 35.15 \\
2 & Chemical Engineering Transactions & 8 & 2.19 & 15 & 1.87 \\
3 & Process Biochemistry & 5 & 1.37 & 246 & 49.20 \\
4 & Journal of Food Science and Technology & 5 & 1.37 & 14 & 2.80 \\
5 & International Food Research Journal & 5 & 1.37 & 5 & 1.00 \\
6 & Carbohydrate Polymers & 4 & 1.09 & 128 & 32.00 \\
7 & International Biodeterioration And Biodegradation & 4 & 1.09 & 33 & 8.25 \\
8 & RSC Advances & 4 & 1.09 & 29 & 7.25 \\
9 & International Journal of Chemtech Research & 4 & 1.09 & 20 & 5.00 \\
10 & Revista Brasileira de Zootecnia & 4 & 1.09 & 20 & 5.00 \\
\hline
\end{tabular}

\footnotetext{
${ }^{\mathrm{a}}$ Total Citations of the document.

${ }^{\mathrm{b}}$ Average Citations per published document.
} 
In terms of journals performance, Bioresource Technology was the most productive with 13 articles, followed by Chemical Engineering Transactions ( 8 articles). Bioresource Technology also presented the highest number of citations (457), followed by Process Biochemistry (246) and Carbohydrate Polymers (128). Process Biochemistry had the highest TC/P score, followed by Bioresource Technology and Carbohydrate
Polymers. It is interesting to note that despite being in second place in the publications, Chemical Engineering Transactions presents TC/P well below the last three mentioned.

Figure 3 illustrates the performance of journals on the use of agroindustrial residues of pineapples.

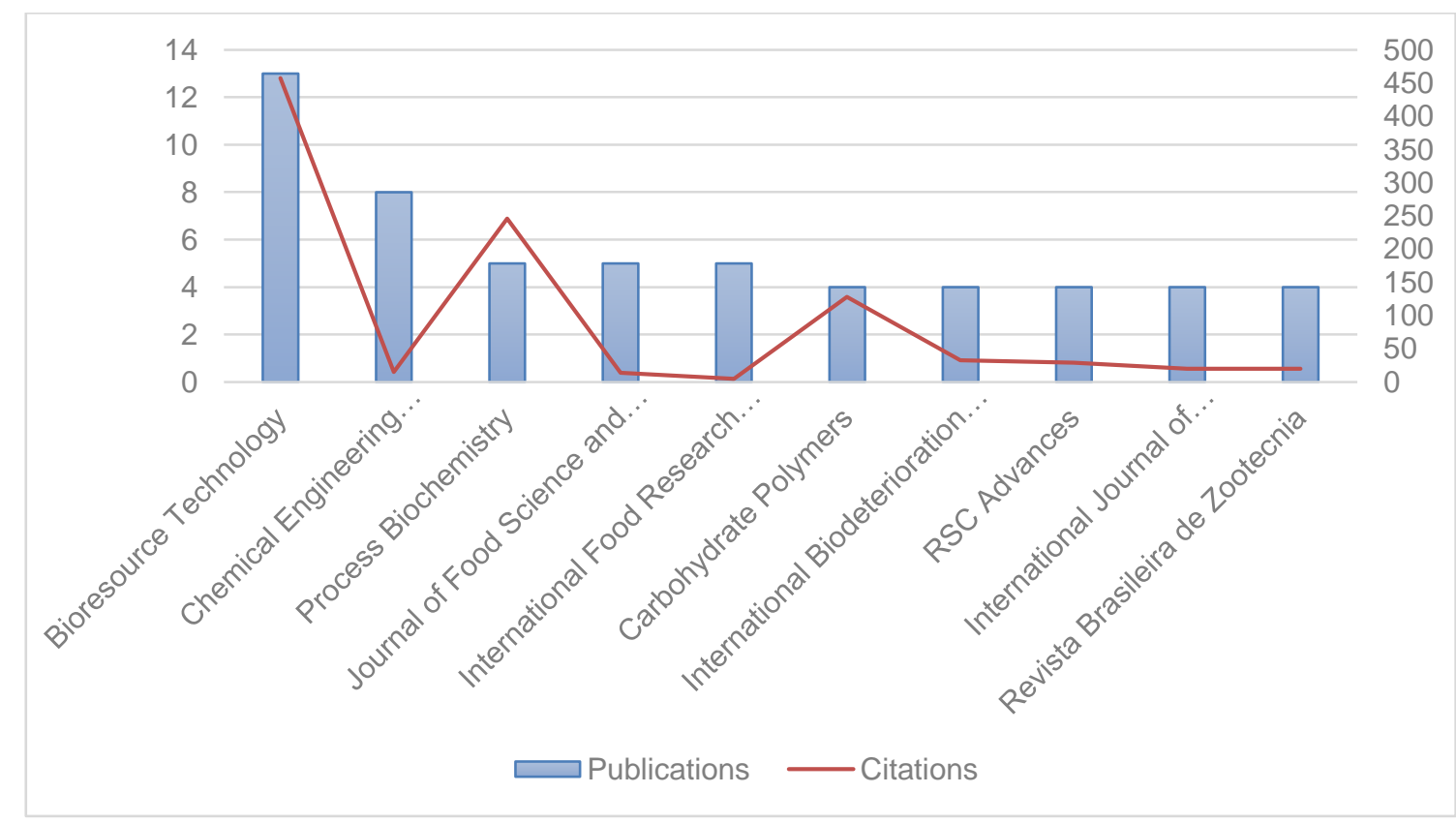

Figure 3: Number of publications and citations in periodicals

The results imply that Bioresource Technology, Process Biochemistry and Carbohydrate Polymers are the leading journals in this area. Other major journals include International Biodeterioration and Biodegradation, RSC Advances, International Journal of Chemtech Research and the Revista Brasileira de Zootecnia.

\subsection{Country}

From the point of view of the countries, institutions from 50 countries were responsible for the publication of the 364 articles related to the use of agroindustrial residues of pineapples. Of the total countries, $40 \%$ contributed with only one document. Table 2 lists the ten most productive countries. 
Table 2: Publications by country, and collaboration between countries

\begin{tabular}{lllll|lll}
\hline$\#$ & Country & n.p. $^{\text {a }}$ & $\%$ & coll $^{\mathrm{b}}$ & Country 1 & Country 2 & n.p. $^{\text {a }}$ \\
\hline 1 & India & 78 & 19.38 & 9 & Thailand & Japan & 5 \\
2 & Brazil & 59 & 16.28 & 4 & India & South Korea & 4 \\
3 & Malaysia & 49 & 15.12 & 6 & India & United States & 3 \\
4 & Thailand & 40 & 12.40 & 15 & Malaysia & Australia & 3 \\
5 & China & 19 & 6.20 & 2 & Thailand & South Korea & 3 \\
6 & Nigeria & 18 & 5.81 & 2 & Thailand & United States & 3 \\
7 & United States & 17 & 5.43 & 20 & Brazil & United States & 2 \\
8 & Mexico & 14 & 3.88 & 1 & Thailand & France & 2 \\
9 & Japan & 13 & 3.49 & 8 & United States & France & 2 \\
10 & Australia & 11 & 3.49 & 4 & United States & South Korea & 2 \\
\hline
\end{tabular}

${ }^{\mathrm{a}}$ Publications number

${ }^{\mathrm{b}}$ Collaboration

From Table 2, it can be seen that the ten most productive are responsible for $87.6 \%$ of all publications, with $63.18 \%$ being distributed among the first four. India has more publications in this area, followed by Brazil, Malaysia and Thailand. In this way, it is understood that the main countries of the researchers related to the residues are also the main producers of the fruit. These countries are emerging economies with favorable climates for the cultivation of pineapples, and the use of waste can represent an important economic activity.

Table 2 also shows the main collaborations between countries. Although the United States (USA) is not ranked among the five most productive countries, it is the most active country for international collaboration in this field with 20 collaborations.

Countries collaborating with the USA include India, Thailand, Brazil, France and South Korea. The USA has collaborated with many countries. On the other hand, India, Brazil and Malaysia, although with more publications, have few collaborations with other countries. It has been found that thirteen nations (such as Portugal, Taiwan, Indonesia, among others) have not collaborated with other countries in their publications.

The United States has the largest cross-country cooperation, maintaining research relationships with 13 countries worldwide by sharing 20 articles, followed by Thailand (6 countries and 15 articles), South Korea (4 countries and 11 articles), India (4 countries and 9 articles), South Africa (9 countries and 9 articles) and Italy ( 8 countries and 8 articles), while South Africa and Italy, despite high collaboration, share only one article with other countries. Highlight the relationship between Japan and Thailand by cooperating five articles.

In relation to the most productive countries, Malaysia (6 articles) and Brazil (4 articles), although highly productive, maintains collaboration with only four and three countries, respectively, indicating that the research is little diversified and restricted to national researchers, while Nigeria, which despite being among the most productive, shared only two articles.

\subsection{Authors}

In total, 1,183 authors wrote contributions to this subject, although only 166 authors participated in more than one document. The authors with the highest number of publications are listed in Table 3, including the respective numbers of published documents, hindex, country of origin and collaboration articles. We see Tambourgi E. B. as the most productive author with 9 articles, followed by Huang H. and Vasiljevic T. with 8 and 7 articles, respectively. 
Franklyn da Cruz LIMA et al.

Table 3: Main authors and main co-authors

\begin{tabular}{|c|c|c|c|c|c|c|c|c|}
\hline \# & Author & n.p. ${ }^{a}$ & h-Index & Country & $\operatorname{coll}^{\mathrm{b}}$ & Author 1 & Author 2 & n.p. ${ }^{a}$ \\
\hline 1 & Tambourgi, E. B. & 9 & 22 & Brazil & 39 & Tambourgi, E. B. & Silveira, E. & 6 \\
\hline 2 & Huang, H. & 8 & 10 & China & 17 & Carreira, R. L. & Silvestre, M.P.C & 6 \\
\hline 3 & Vasiljevic, T. & 7 & 24 & Australia & 21 & Vasiljevic, T. & Donkor, O. N. & 4 \\
\hline 4 & Silveira, E. & 6 & 6 & Brazil & 33 & Vasiljevic, $\mathrm{T}$. & Sah, B. N. P. & 4 \\
\hline 5 & Carreira, R. L. & 6 & 5 & Brazil & 28 & Vasiljevic, T. & McKechnie, S. & 4 \\
\hline 6 & Silvestre, M.P.C. & 6 & 17 & Brazil & 28 & Huang, H. & Dai, H. & 4 \\
\hline 7 & Zakaria, Z. A. & 5 & 11 & Brazil & 21 & Huang, H. & $\mathrm{Hu}, \mathrm{X}$. & 4 \\
\hline 8 & Ahmad, W. A. & 5 & 11 & Malaysia & 19 & Zakaria, Z. A. & Ahmad, W. A. & 3 \\
\hline 9 & $\mathrm{Hu}, \mathrm{X}$. & 5 & 4 & China & 16 & Jamal, P. & Alam, M. Z. & 3 \\
\hline 10 & Jamal, P. & 5 & 11 & Malaysia & 16 & Jamal, P. & Saheed, O. K. & 3 \\
\hline
\end{tabular}

${ }^{\mathrm{a}}$ Publications number

${ }^{\mathrm{b}}$ Collaboration

The h-index of each author was obtained from Scopus, being a non-static indicator to measure the author's productivity and the impact of his research. In general, it implies that the total number of articles published by a person is quoted at least $\mathrm{h}$ times.

However, regarding the h-index, the number of publications are not proportional to the scores of this indicator. The reason for this can be attributed to the fact that studies related to the use of pineapple residues require the involvement of researchers from different fields, highlighting those that exert a greater influence in their area of research, as is the case of Vasiljevic T. (agricultural and biological sciences).

In order to analyze the collaboration between authors, Table 3 also shows the main authors and main coauthors in this field of research. Interestingly, the authors listed in main authors are also present in main co-authors, indicating knowledge integration of different authors.

Table 3 shows collaboration within a given country, such as Tambourgi, Silveira, Carreira and Silvestre in
Brazil; Huang, Dai and Hu in China; Jamal and Alam in Malaysia, and Vasiljevic and Sah in Australia. Therefore, the collaborations among the most productive authors are among authors from the same country.

Looking at Table 3 , it is possible to verify that the authors who most shared articles related to the use of agroindustrial residues of pineapples were Tambourgi E.B. and Silveira E., both from the Campinas State University, and Silvestre M.P.C. and Carreira R.L., both from the Federal University of Minas Gerais. This shows that despite the high collaboration observed, the Brazilian scientific production in this field is concentrated among national authors, since Brazil has low international collaboration.

\subsection{Institutions}

A total of 158 institutions published articles on the use of agroindustrial residues of pineapple, of which 57 (36.1\%) had only one publication. Table 4 lists the ten most productive organizations. 
Table 4: Contribution of institutions

\begin{tabular}{llll}
\hline$\#$ & Institution & Country & Publications \\
\hline 1 & Universiti Teknologi Malaysia & Malaysia & 19 \\
2 & Universidade Estadual de Campinas & Brazil & 14 \\
3 & Universidade de São Paulo - USP & Brazil & 12 \\
4 & South China University of Technology & China & 10 \\
5 & Kasetsart University & Thailand & 9 \\
6 & Universidade Federal de Minas Gerais & Brazil & 8 \\
7 & Central Food Technological Research Institute Índia & India & 7 \\
8 & Victoria University Melbourne & Australia & 7 \\
9 & Universiti Putra Malaysia & Malaysia & 6 \\
\hline 10 & Universiti Sains Malaysia & Malaysia & \\
\hline
\end{tabular}

From Table 4 it can be seen that Malaysia has three of the ten most productive institutions, including Universiti Teknologi Malaysia, which has the largest number of publications. India, although the most productive country, has only one institution (Central Food Technological Research Institute India), indicating a probable production distributed in that country.

Brazil also has three of the ten most productive institutions. The Campinas State University presents greater national production, followed by the University of São Paulo and the Federal University of Minas Gerais. As the second most productive country (section

Table 5: Frequently used keywords

\begin{tabular}{lll}
\hline$\#$ & Keywords & Frequency \\
\hline 1 & Bromelain & 33 \\
2 & Pineapple & 32 \\
3 & Pineapple waste & 27 \\
4 & Pineapple peel & 16 \\
5 & Fermentation & 16 \\
6 & Adsorption & 12 \\
7 & Enzimatic hidrolysis & 9 \\
8 & Aspergilus niger & 8 \\
9 & Bioethanol & 8 \\
10 & Ananas comosus & 8 \\
\hline
\end{tabular}

3.4) and with more than thirty productive organizations, it is concluded that the rest of the Brazilian production is well distributed among the other institutions.

\subsection{Keywords}

In order to understand a subject during a specific period, it is possible to use keywords which can provide important information. In this sense, the present work extracted 1,061 keywords defined by the authors of the articles, some of them being similar. The most frequently adopted are listed in Table 5. 
From Table 5 it is concluded that the most used keywords are related to the words bromelain, pineapple and fermentation.

As mentioned in section 3.1, studies on the utilization of agroindustrial pineapple residues can be divided into periods according to annual publications. Thus, the keywords were identified in two periods (1967-2007 and 2008-2017) in order to verify the main research themes. Figures 4 and 5 show the most used keywords and their respective networks during the years 19672007 (165 words) and 2008-2017 (947 words), respectively.

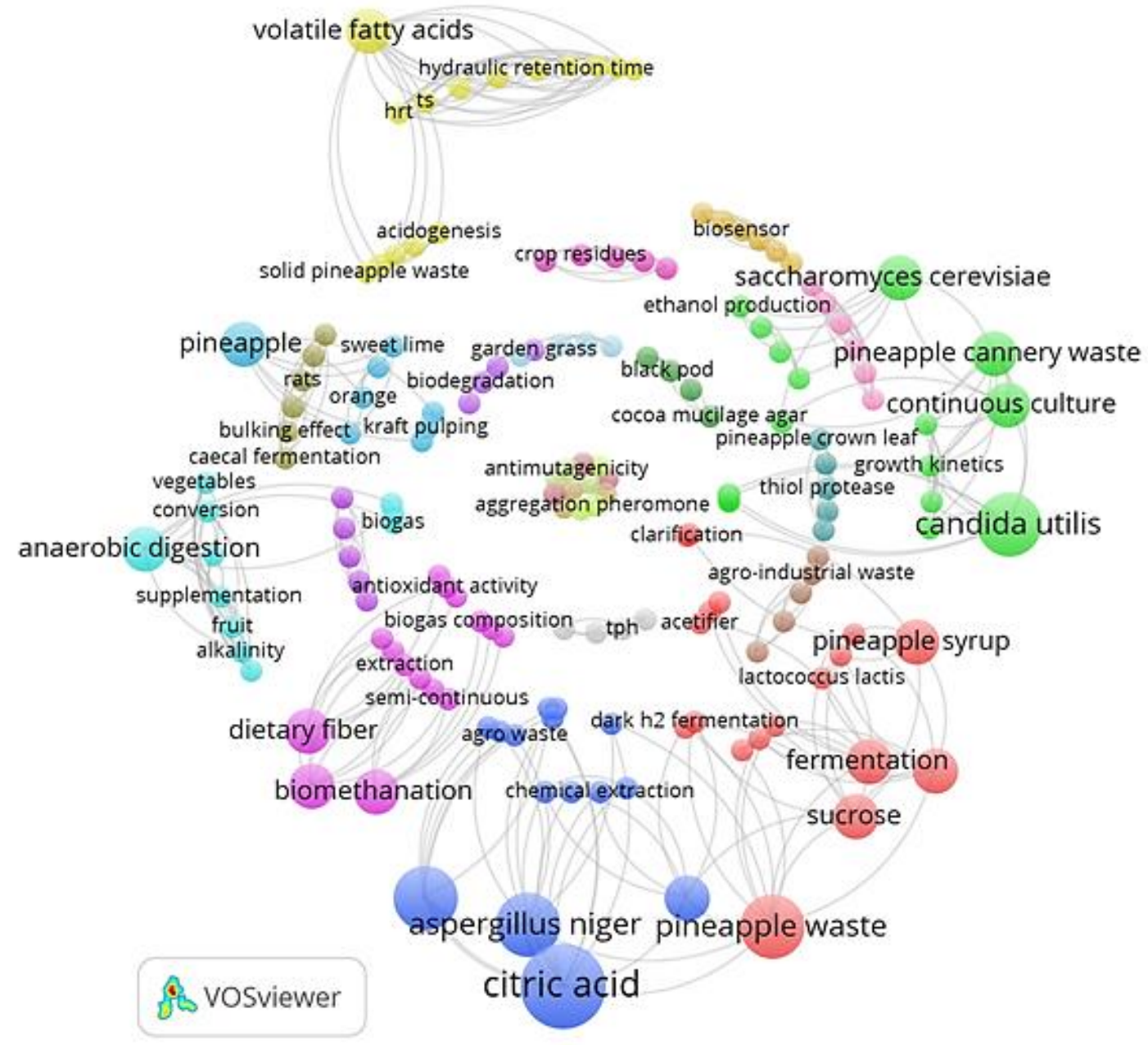

Figure 4: Keywords frequently used in the period 1967-2007 


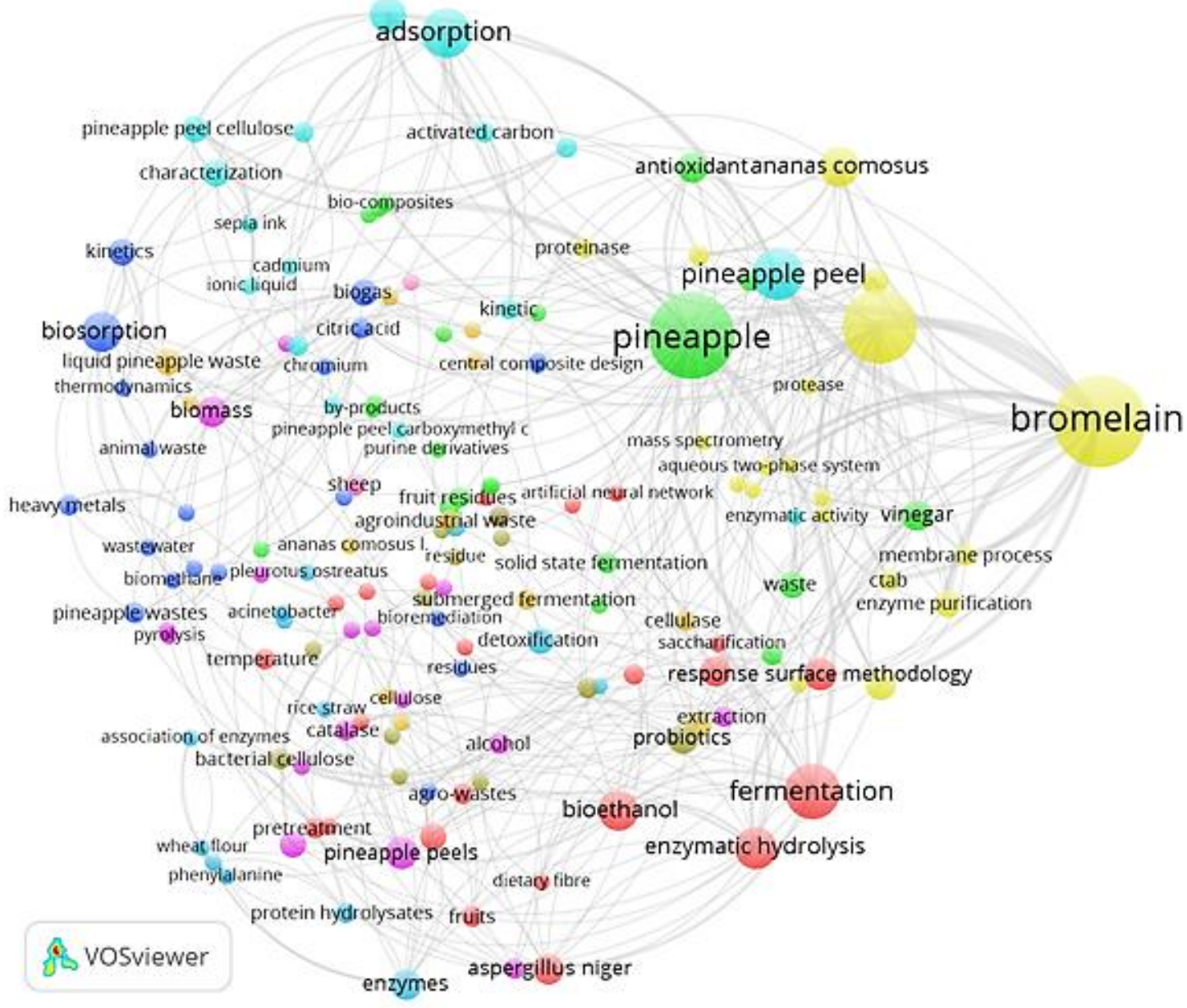

Figure 5: Keywords frequently used in the period 2008-2017

There are circles, in Figures 4 and 5, whose sizes serve to demonstrate the use of the keyword, i.e. the larger the circle size the more often the keyword was used. The lines are used to indicate the number of times that two keywords were used together. From Figure 4, it is concluded that during the first stage (1967-2007), the researchers focused mainly on the contents of pineapple residue, citric acid production and fermenting microorganisms, such as Candida utilis (Hennenberg) Lodder \& Kreger, Aspergillus niger van Tieghem and Saccharomyces cerevisiae Meyen ex E.C. Hansen. In the second stage (2008-2017), the topic of residues of pineapple and fermentation remained. In addition, new topics related to bromelain and substance adsorption have become a frequent target of recent research.

In this study, the keywords most frequently used by the authors of the articles, without the use of synonym grouping, were presented, so that the keywords "Ananas comosus" and "pineapple" are presented as distinct terms in Figure 5. Nevertheless, these words are related and arranged nearby and connected through the lines by the software.

\subsection{Subject Type}

The use of agroindustrial residue of pineapple has strong economic appeal, having seen the amount of applications. When conducting an analysis of the summary of the 364 articles selected, it was verified that certain subjects were presented with more frequency. The five main themes studied in the research on the use of agroindustrial residues of pineapples were responsible for accounting for more than half of the publications (204 articles or $56.04 \%$ ).

Among the most studied (56.04\%), the highest use of the residue as a protein supplement $(14.56 \%)$, source of enzymes (11.54\%), biofuel (10.44\%), bromelain $(10.16 \%)$ and use as adsorbent $(9.34 \%)$. Other applications involve the production of acids, antioxidant phenols and vinegar / wine. 
Protein supplement

The use of agroindustrial residues of pineapple as a supplement usually involves the use of microorganisms for protein enrichment. For example, Mensah and Twumasi (2017) used pineapple residues as a substrate for production of Single Cell Protein (SCP) with yeast Saccharomyces cerevisiae as inoculum. According to its results, it was concluded that residues from the food processing industry serve as good substrates for SCP production, which presents high benefit. In this way, protein-rich foods for animals and humans can be produced.

According to Damasceno et al. (2016), the pineapple peel flour is high in fiber and can be introduced into cereal bars as food. In their work, they evaluated the use of this flour in different concentrations in cereal bars, concluding that this material is a good alternative to be introduced in the human diet while minimalizing the environmental impact.

Other work on supplements involves the use of pineapple residues as cattle silage (Yang et al., 2016; Braga et al., 2016), piglet feeding (Ramos et al., 2016) and forage for dairy cows (Kraiprom et al., 2013), presenting an alternative food in periods of scarcity or as food of low cost.

\section{Enzymes}

In recent work, Selvakumar and Sivashanmugam (2017) produced lipase from pineapple skin. According to the authors, these enzymes are important because they can be used in the hydrolysis of the acylglycerols present in fatty acids and glycerol. They also investigated its use in the conversion of palm oil into biodiesel, obtaining yield $88.63 \%$.

Arun and Sivashanmugam (2015) produced different types of enzymes from pre-consumed pineapple residues. These enzymes were used in the treatment of activated sludge, solubilizing insoluble organic compounds in soluble compounds, which can later be treated to produce methane or hydrogen.

Silvestre et al. (2012) performed the extraction of protease from pineapple peels. When evaluating the stability, they verified the maintenance of the initial activity in $60.9 \%$ and $53.7 \%$ for the different $\mathrm{pH}$ and temperature conditions, respectively.

Other studies involved, for example, the production of amylase (Orlandelli et al., 2017), xylanase (Harris \& Chidambaram, 2015) and cellulase (Kannahi \& Elangeswari, 2015).

\section{Biofuel}

Shamsul et al. (2017) performed the production of biomethane and biometanol in batch bioreactor using pineapple peels as one of the substrates. They verified ideal temperature, concentration and retention times for production, obtaining $2.49 \%$ methanol with $74.24 \%$ methane.

Ogunleye et al. (2016) used pineapple residues in mixture with animal waste for the production of biomethane. They used 1.51 anaerobic digesters and incubated for 10 weeks. When using the pineapple residues, they obtained increased yield and shorter startup time for the generation of biomethane.

Other studies have involved biomethanization of pineapple peels (Aworanti et al., 2017) and bioethanol production (Conesa et al., 2016; Venkateswarulu et al., 2015), contributing as a biotechnological alternative to the use of fossil fuels.

\section{Bromelain}

Bromelain is a group of proteolytic enzymes found in pineapple tissues. Due to its high activity, it can potentially be used in the cosmetic, pharmaceutical and food industries (Spir et al., 2015).

Chaurasiya et al. (2015) used reverse micelle extraction (RME) for the separation and purification of bromelain from the pineapple nucleus. This bromelain was used in beef softening and compared to commercial bromelain. The results indicated a high recovery of activity $(85 \%)$ and a greater reduction of tenacity $(52.1 \%)$ compared to commercial bromelain $(26.7 \%)$.

Work on the separation, extraction and purification of bromelain from pineapple residues were carried out, for example, by Coêlho et al. (2015), Martins et al. (2014) and Novaes et al. (2013).

\section{Adsorption/Absorption}

Solidum (2013) evaluated the ability to remove heavy metals from water by pineapple peels. They analyzed the kinetic parameters of the removal of lead and cadmium in contaminated waters, varying $\mathrm{pH}$, contact time and metal concentration. According to the authors, the use of these residues in the absorption of the metals presents considerable profitability.

Shifera et al. (2017) conducted studies on the removal of lead (II) and chromium (VI) present in water. They concluded that the adsorption on pineapple peels is viable, besides being spontaneous and exothermic. 
Gandhi et al. (2012) analyzed the removal of fluoride from water from pineapple peel powder. The results showed that the use of residues as adsorbents are a viable alternative, because they have significant removal capacity and low cost.

Other examples include adsorption of methylene blue (Yamuna \& Kamaraj, 2016), nickel (Dotto et al., 2016; Rao \& Khan, 2017) and copper (Romero-Cano et al., 2017).

\section{Other applications}

Other applications involve the production of different compounds, such as: antioxidant phenols (Nor Halaliza \& Zulkifly, 2017; Alias \& Abbas, 2017), acids (Tang et al., 2014; Lun et al., 2014), wine/vinegar (Roda et al., 2017; Praveena \& Estherlydia, 2014), bacterial cellulose.(Kumbhar et al., 2015), acetone-butanolethanol (ABE) using Clostridium acetobutylicum McCoy et al. Emend. Keis et al.(Khedkar et al., 2017), hydrogel (Dai \& Huang, 2016), phenolic antioxidants using Rhizopus oligosporus Saito(Correia et al., 2004), yellowish orange pigment from Chryseobacterium artocarpi Venil et al. 2014(Aruldass et al., 2016).

\subsection{Citation analysis}

Citation analysis is a widely used method for assessing the academic performance of a researcher. When one article is quoted by another, it means that the search results of that article can provide useful information for others, the relevance of which is proportional to the number of quotes.

The simplest way in citation analysis is to count the number of citations received by a document. However, authors can cite their own articles, or some citations can be negative. Thus, total citations do not always indicate the true value of an article (Geng et al., 2017).

Thus, the citation analysis was based on the average number of citations per year after publication (TC/Y), since recently published articles are less likely to be cited. Table 6 shows the top ten articles based on this indicator.

Table 6: Most cited articles by year of publication

\begin{tabular}{lllll}
\hline$\#$ & Author $^{\mathrm{a}}$ & Periodic & $\mathrm{TC} / \mathrm{Y}^{\mathrm{b}}$ & $\mathrm{TC}^{\mathrm{c}}$ \\
\hline 1 & Hameed (2009) & Journal of Hazardous Materials & 17.3 & 156 \\
2 & De Oliveira (2009) & Food Chemistry & 13.4 & 121 \\
3 & Castro (2011) & Carbohydrate Polimers & 13.1 & 92 \\
4 & Bansal (2012) & Waste Management & 13.0 & 78 \\
5 & Foo (2012) & Microporous and Mesoporous Materials & 9.7 & 58 \\
6 & Imandi (2008) & Bioresource Technology & 9.4 & 94 \\
7 & Idris (2006) & Process Biochemistry & 8.6 & 103 \\
8 & Umesh hebbar (2008) & Bioresource Technology & 8.0 & 80 \\
9 & Nanda (2016) & Energy Conversion and Management & 8.0 & 16 \\
10 & Mahamad (2015) & International Biodeterioration and & 7.3 & 22 \\
\hline
\end{tabular}

\footnotetext{
${ }^{\mathrm{a}}$ Data referring to the first author.

b Annual average citations.

c Total citations.
}

In total, 94 articles $(25.8 \%)$ were not cited. Table 6 shows that the work done by Hameed et al. (2009) has a great popularity, being also the one with the highest $\mathrm{TC} / \mathrm{Y}$ index. Soon this is the most credible study to be quoted. His research explored the use of the waste as a low cost adsorbent of methylene blue aqueous solution, studying adsorption kinetics and isotherms.
Also noteworthy for the studies carried out by Nanda et al. (2016), on supercritical water gasification of pineapple bark for bio-gas production, and by Mahamad et al. (2015), on dye worship, which, although recent and with few quotations, present a high TC/Y value. 


\section{CONCLUSIONS}

Based on the data extracted from the Scopus database, this paper investigated the development characteristics of publications (from 1967 to 2017) on the use of agroindustrial residues of pineapples, using bibliometrics analysis. The studies that contributed to this research theme involve 21 different academic areas, being $40.1 \%$ in the area of agriculture and biological sciences, $23.1 \%$ biochemistry and genetics and $22.0 \%$ in chemical engineering.

Although there have been publications on the subject in the last 40 years, $82 \%$ of these publications have been published in the last decade, which shows a growing trend of research in this area in the last years. The growth can possibly be attributed to the growing environmental concern and high costs of agroindustrial waste disposal.

India, Brazil and Malaysia collaborate weakly with other countries despite producing large number of publications. The United States is the leader in international collaboration. However, Brazil has three of the ten most productive institutions, with Campinas State University being nationally the most prominent. Universiti Teknologi Malaysia is the most productive institution.

Finding ways to reuse waste brings benefit not only to the environment but also to industries. During this work, several studies on the reuse of pineapple residues were found, such as: protein supplement, source of enzymes, biofuel, bromelain, use of adsorbent and production of acids, antioxidant phenols, vinegar and wine. Thus, this study provides a framework and serve as a base for future studies into the identification of influential authors, journals, works, institutions and subjects in the field of agroindustrial residues of pineapple helping new researches and interactions in this area.

\section{ACKNOWLEDGEMENTS}

The authors thank to Support to Innovation, Science and Technology Foundation of the State of Sergipe (Fundação de Apoio à Pesquisa e à Inovação Tecnológica do Estado de Sergipe-FAPITEC-SE), National Council for Scientific and Technological
Development (CNPq/Brazil), Coordination of Improvement of Higher Level Personnel (Coordenação de Aperfeiçoamento de Pessoal de Nível SuperiorCAPES/Brazil).

\section{REFERENCES}

Aleixandre, J.L., Aleixandre-Tudó, J.L., Bolaños-Pizarro, M., Aleixandre-Benavent, R. (2015). Mapping the scientific research in organic farming: a bibliometric review. Scientometrics, 105, 295-309. doi:10.1007/s11192-015-1677-4

Alexandre, H.V., da Silva, F.L.H., Gomes, J.P., da Silva, O.S., Carvalho, J.P.D., de Lima, E.E. (2013). Drying kinetics of enriched pineapple residue | Cinética de secagem do resíduo de abacaxi enriquecido. Revista Brasileira de Engenharia Agrícola e Ambiental, 17 (6), 640-646. doi:10.1590/S141543662013000600010

Alias, N.H., \& Abbas, Z. (2017). Preliminary investigation on the total phenolic content and antioxidant activity of pineapple wastes via microwave-Assisted extraction at fixed microwave power. Chemical Engineering Transactions, 56, 1675-1680.

Allen, T.J. (1969). Information needs and uses. Annual Review of Information Science and Technology, 4, 329.
Aruldass, C.A., Aziz, A., Venil, C.K., Khasim, A.R., Ahmad, W.A. (2016). Utilization of agro-industrial waste for the production of yellowish-orange pigment from Chryseobacterium artocarpi CECT 8497. International Biodeterioration and Biodegradation, 113, 342-349. doi:10.1016/j.ibiod.2016.01.024

Arun, C., \& Sivashanmugam, P. (2015). Solubilization of waste activated sludge using a garbage enzyme produced from different pre-consumer organic waste. RSC Advances, 5 (63), 51421-51427. doi:10.1039/C5RA07959D

Aworanti, O.A., Agarry, S.E., Ogunleye, O.O. (2017). Biomethanization of the mixture of cattle manure, pig manure and poultry manure in co-digestion with waste peels of pineapple fruit and content of chicken-gizzard - part ii: Optimization of process variables. The Open Biotechnology Journal, 11, 54-71. doi:10.2174/1874070701711010054

Bartol, T., \& Mackiewicz-Talarczyk, M. (2015). Bibliometric Analysis of Publishing Trends in Fiber Crops in Google Scholar, Scopus, and Web of 
Science. Journal of Natural Fibers, 12 (6), 531-541. doi:10.1080/15440478.2014.972000

Borges, C.D., Chim, J.F., Leitão, A.M., Pereira, E., Luvielmo, M.D.M. (2004). Produção de suco de abacaxi obtido a partir dos resíduos da indústria conserveira. Boletim do Centro de Pesquisa de Processamento de Alimentos, 22 (1), 23-34. doi:10.5380/cep.v22i1.1177

Braga, A.P., Amâncio, A.V.A.F., Gonçalves, J. S, Cortes Assis, L.C.S.L.C, Souza, C.M.S., Maia, I.S.A.S., Gerra, D.G.F. (2016). Ruminal degradability of agroindustrial fruit residues. Semina: Ciências Agrárias, 37(1), 279-292. doi:10.5433/16790359.2016v37n1p279

Brito Neto, J.F., Pereira, W.E., Sobrinho, R.G.S., Barbosa, J. A, Santos, D.P. (2008). Productive aspects of the family and commercial pineapple culture in the state of Paraíba. Caatinga, 21 (4), 43-50.

Chaurasiya, R.S., Sakhare, P.Z., Bhaskar, N., Hebbar, H.U. (2015). Efficacy of reverse micellar extracted fruit bromelain in meat tenderization. Journal of Food Science and Technology, 52(6), 3870-3880. doi:10.1007/s13197-014-1454-z

Chen, H., Jiang, W., Yang, Y., Yang, Y., Man, X. (2016). State of the art on food waste research: a bibliometrics study from 1997 to 2014. Journal of Cleaner Production, $\quad 140, \quad 840-846$. doi:10.1016/j.jclepro.2015.11.085

Coêlho, D.D.F., Silva, C.A., Machado, C.S., Silveira, E., Tambourgi, E.B. (2015). Use of artificial neural networks to predict aqueous two-phases system optimal conditions on Bromelain's purification. Chemical Engineering Transactions, 43, 1417-1422.

Conesa, C., Seguí, L., Laguarda-Miró, N., Fito, P. (2016). Microwaves as a pretreatment for enhancing enzymatic hydrolysis of pineapple industrial waste for bioethanol production. Food and Bioproducts Processing, 100, 203-213. doi:10.1016/j.fbp.2016.07.001

Correia, R.T.P., McCue, P., Magalhães, M.M.A., Macêdo, G.R., Shetty, K. (2004). Production of phenolic antioxidants by the solid-state bioconversion of pineapple waste mixed with soy flour using Rhizopus oligosporus. Process Biochemistry, 39 (12), 21672172. doi:10.1016/j.procbio.2003.11.034

Costa, C., Biocca, M., Pallottino F., Nardi P., Figorilli S. (2017). Structure of the precision agriculture research in Italy from 2000 to 2016: A term mapping approach. Chemical Engineering Transactions, 58, 643-648.

Dai, H., Huang, H. (2016). Modified pineapple peel cellulose hydrogels embedded with sepia ink for effective removal of methylene blue. Carbohydrate Polymers, 148, 1-10. doi:10.1016/j.carbpol.2016.04.040
Damasceno, K. A, Gonçalves, C.A. S., Pereira, G. S., Costa, L.L, Campagnol, P.C.B, Almeida, P. L, Arantes-Pereira, L. (2016). Development of Cereal Bars Containing Pineapple Peel Flour (Ananas comosus L. Merril). Journal of Food Quality, 39 (5), 417-424. doi:10.1111/jfq.12222

Díaz-Vela, J., Totosaus, A., Escalona-Buendía, H.B., Pérez-Chabela, M.L. (2017). Influence of the fiber from agro-industrial co-products as functional food ingredient on the acceptance, neophobia and sensory characteristics of cooked sausages. Journal of Food Science and Technology, 54 (2), 379-385. doi:10.1007/s13197-016-2473-8

Dotto, G.L., Meili, L., De Souza Abud, A.K., Tanabe, E.H., Bertuol, D.A., Foletto, E.L. (2016). Comparison between Brazilian agro-wastes and activated carbon as adsorbents to remove $\mathrm{Ni}(\mathrm{II})$ from aqueous solutions. Water Science \& Technology, 73 (11), 2713-2721. doi:10.2166/wst.2016.095

Elsevier (2018). Scopus. Retrieved from https://www.elsevier.com/_data/assets/pdf_file/0008/ 208772/ACAD_R_SC_FS.pdf

Ensslin, L., Ensslin, S.R., Pinto, H. de M. (2013). Processo de investigação e análise bibliométrica: avaliação da qualidade dos serviços bancários. Revista de Administração Contemporânea, 17 (3), 325-349. doi:10.1590/S1415-65552013000300005

Fagundes, N.S., \& Fagundes, N.S. (2010). Restos culturais do abacaxizeiro na alimentação de ruminantes. Revista Eletrônica Nutritime, 113 (7), 1243-1247.

FAO (2015). FAOSTAT database collections. Retrieved from http://www.oecd-ilibrary.org/agriculture-andfood/oecd-fao-agricultural-outlook-2015_agr_outlook2015-en

Ferrari, R.A., Colussi, F., Ayub, R.A. (2004). Caracterização de subprodutos da industrialização do maracujá-aproveitamento das sementes. Revista Brasileira de Fruticultura, 26 (1), 101-102. doi:10.1590/S0100-29452004000100027

Gandhi, N., Sirisha, D., Chandra Shekar, K.B., Asthana, S. (2012). Removal of fluoride from water and waste water by using low cost adsorbents. International Journal of ChemTech Research, 4 (4), 1646-1653.

Geng, Y., Chen, W., Liu, Z., Chiu, A.S.F., Han, W., Liu, Z., Zhong, S., Cui, X. (2017). A bibliometric review: Energy consumption and greenhouse gas emissions in the residential sector. Journal of Cleaner Production, 159, 301-316. doi:10.1016/j.jclepro.2017.05.091

Hameed, B.H., Krishni, R.R., Sata, S.A. (2009). A novel agricultural waste adsorbent for the removal of cationic dye from aqueous solutions. Journal of Hazardous Materials, 162 (1), 305-311. doi:10.1016/j.jhazmat.2008.05.036 
Harris, S. A.D., \& Chidambaram, R. (2015). Production of xylanase from watermelon rind by bacillus weihenstephanesis strain ANR1. International Journal of ChemTech Research, 8 (5), 1-5.

Hočevar, M., \& Bartol, T. (2016). Agriculture vs.Social sciences: subject classification and sociological conceptualization of rural tourism in Scopus and Web of Science. Acta agriculturae Slovenica, 108 (1), 3344. doi:10.14720/aas.2016.108.1.1

IBGE (2017). IBGE. Levantamento Sistemático da Produção Agrícola. Retrieved from ftp://ftp.ibge.gov.br/Producao_Agricola/Levantamento _Sistematico_da_Producao_Agricola_[mensal]/Fascic ulo/2015/lspa_201501.pdf

Isitua, C.C., \& Ibeh, N.I. (2010). Novel method of wine production from banana (musa acuminata) and pineapple (ananas comosus) wastes. African Journal of Biotechnology, 9 (44), 7521-7524. doi:10.5897/AJB10.999

Kannahi, M., \& Elangeswari, S. (2015). Enhanced production of cellulase on different fruit peel under submerged fermentation. International Journal of Pharmaceutical Sciences Review and Research, 32 (2), 161-165.

Ketnawa, S., Chaiwut, P., Rawdkuen, S. (2012). Pineapple wastes: A potential source for bromelain extraction. Food and Bioproducts Processing, 90 (3), 385-391. doi:10.1016/j.fbp.2011.12.006

Khedkar, M.A., Nimbalkar, P.R., Gaikwad, S.G., Chavan, P. V., Bankar, S.B. (2017). Sustainable biobutanol production from pineapple waste by using Clostridium acetobutylicum B 527: Drying kinetics study. Bioresource Technology, 225, 359-366. doi:10.1016/j.biortech.2016.11.058

Kraiprom, T., Prasanpanich, S., Kungmun, P., Sivijchai, S., Tumwasorn, S. (2013). Effect of fermented by-product and rice straw on milk yield and fatty acid composition in dairy cows. Kasetsart Journal Natural Science, 47 (2), 217-227.

Kumbhar, J.V., Rajwade, J.M., Paknikar, K.M. (2015). Fruit peels support higher yield and superior quality bacterial cellulose production. Applied Microbiology and Biotechnology, 99 (16), 6677-6691. doi:10.1007/s00253-015-6644-8

Lun, O.K., Wai, T.B., Ling, L.S. (2014). Pineapple cannery waste as a potential substrate for microbial biotranformation to produce vanillic acid and vanillin. International Food Research Journal, 21 (3), 953958.

Madurai, R., John, S., Bhavani, I.L.G. (2010). Study on preparation, nutrient analysis and shelf life of biovinegar and its formulations. Biosciences Biotechnology Research Asia, 7 (2), 849-855.
Mahamad, M.N., Zaini, M.A.A., Zakaria, Z.A. (2015). Preparation and characterization of activated carbon from pineapple waste biomass for dye removal. International Biodeterioration \& Biodegradation, 102, 274-280. doi:10.1016/j.ibiod.2015.03.009

Manosroi, A., Chankhampan, C., Pattamapun, K., Manosroi, W., Manosroi, J. (2014). Antioxidant and gelatinolytic activities of papain from papaya latex and bromelain from pineapple fruits. Chiang Mai Journal of Science, 41 (3), 635-648.

Mao, G., Huang, N., Chen, L., Wang, H. (2018). Research on biomass energy and environment from the past to the future: A bibliometric analysis. Science of the Total Environment, 635, 1081-1090. doi:10.1016/j.scitotenv.2018.04.173

Martins, B.C., Rescolino, R., Coelho, D.F., Zanchetta, B., Tambourgi, E.B., Silveira, E. (2014). Characterization of Bromelain from Ananas Comosus Agroindustrial Residues Purified by Ethanol Factional Precipitation. Chemical Engineering Transactions, 37, 781-786.

Marx, W., Haunschild, R., Bornmann, L. (2017). Climate change and viticulture - A quantitative analysis of a highly dynamic research field. Journal of Grapevine Research, 56 (1), 35-43. doi:10.3390/cli5030046

Marx, W., Haunschild, R., Bornmann, L. (2017). Global warming and tea production - The bibliometric view on a newly emerging research topic. Climate, 5 (3), 46. doi:10.3390/cli5030046

Mensah, J.K.M., \& Twumasi, P. (2017). Use of pineapple waste for single cell protein (SCP) production and the effect of substrate concentration on the yield. Journal of Food Process Engineering, 40 (3), e12478. doi:10.1111/jfpe. 12478

Milanez, D.H., Noyons, E., Faria, L.I.L. (2016). A delineating procedure to retrieve relevant publication data in research areas: the case of nanocellulose. Scientometrics, $107 \quad$ (2), 627-643. doi:10.1007/s11192-016-1922-5

Morgado, I.F., Aquino, C.N.P., Terra, D.C.T. (2004). Aspectos econômicos da cultura do abacaxi: sazonalidade de preços no Estado do Rio de Janeiro. Revista Brasileira de Fruticultura, 26 (1), 44-47. doi:10.1590/S0100-29452004000100013

Mugnaini, R., Jannuzzi, P. de M., Quoniam, L. (2004). Indicadores bibliométricos da produção científica brasileira: uma análise a partir da base Pascal. Ciência da Informação, 33 (2), 123-131. doi:10.1590/S010019652004000200013

Nakthong, N., Wongsagonsup, R., Amornsakchai, T. (2017). Characteristics and potential utilizations of starch from pineapple stem waste. Industrial Crops and Products, 105, 74-82. doi:10.1016/j.indcrop.2017.04.048 
Nanda, S., Isen, J., Dalai, A.K., Kozinski, J.A. (2016). Gasification of fruit wastes and agro-food residues in supercritical water. Energy Conversion and Management, $\quad 110, \quad 296-306$. doi:10.1016/j.enconman.2015.11.060

Navid, S., Hilmi, M., Sazili, A.Q., Sheikhlar, A. (2010). Effects of papaya leaf meal, pineapple skin meal and vitamin D3 supplementation on meat quality of spent layer chicken. Journal of Animal and Veterinary Advances, $\quad 9 \quad$ (22), 2873-2876. doi:10.3923/javaa.2010.2873.2876

Nor Halaliza, A., \& Zulkifly, A. (2017). Microwaveassisted extraction of phenolic compound from pineapple skins: The optimum operating condition and comparison with soxhlet extraction | Pengekstrakan sebatian fenolik daripada kulit nenas dengan bantuan gelombang mikro: Pengoptimuman keadaan pen. The Malaysian Journal of Analytical Sciences, 21 (3), 60699. doi:10.17576/mjas-2017-2103-18

Novaes, L.C.L., Ebinuma, V.C.S., Mazzola, P.G., Júnior, A.P. (2013). Polymer-based alternative method to extract bromelain from pineapple peel waste. Biotechnology and Applied Biochemistry, 60 (5), 527535. doi:10.1002/bab.1121

Ogunleye, O.O., Aworanti, O.A., Agarry, S.E., Aremu, M.O. (2016). Enhancement of animal waste biomethanation using fruit waste as co-substrate and chicken rumen as inoculums. Energy Sources, 38 (11), 1653-1660. doi:10.1080/15567036.2014.933286

Orlandelli, R.C., Santos, M.S., Polonio, J.C., de Azevedo, J.L., Pamphile, J.A. (2017). Use of agro-industrial wastes as substrates for $\alpha$-amylase production by endophytic fungi isolated from Piper hispidum Sw. I Uso de resíduos agroindustriais para a produção de $\alpha$ amilase por fungos endofíticos isolados de Piper hispidum Sw.. Acta Scientiarum Technology, 39 (3), 255-261. doi:10.4025/actascitechnol.v39i3.30067

Pelizer, L.H., Pontieri, M.H., Moraes, I. de O. (2007). Utilização de Resíduos Agro-Industriais em Processos Biotecnológicos como Perspectiva de Redução do Impacto Ambiental. Journal of Technology Management \& Innovation, 2 (1), 118-127.

Praveena, R. J., \& Estherlydia, D. (2014). Comparative study of phytochemical screening and antioxidant capacities of vinegar made from peel and fruit of pineapple (Ananas comosus L.). International Journal of Pharma and Bio Sciences, 5 (4), 394-403.

Ramos, G.F., Júnior, C.D.S., Oliveira, J.A., Vasconcelos, T.S., Budiño, F.E.L., Ruiz, U.S. (2016). Performance, diarrhea frequency, feces production and costs of diets with increasing levels of pineapple byproducts in weaned piglets | Desempenho, frequência de diarreia, produção de fezes e custos de dietas com teores crescentes de farelo de abacaxi par. Arquivo Brasileiro de Medicina Veterinária e Zootecnia, 68 (6), 15051515. doi:10.1590/1678-4162-8422
Rao, R.A.K., \& Khan, U. (2017). Adsorption of Ni(II) on alkali treated pineapple residue (Ananas comosus L.): Batch and column studies. Groundwater Sustainable Development, 5 , doi:10.1016/j.gsd.2017.08.002

Richardson, K.C. (1967). Submerged acetification of a vinegar base produced from waste pineapple juice. Biotechnology and Bioengineering, 9 (2), 171-186. doi:10.1002/bit.260090204

Roda, A., Lucini, L., Torchio, F., Dordoni, R., De Faveri, D.M., Lambri, M. (2017). Metabolite profiling and volatiles of pineapple wine and vinegar obtained from pineapple waste. Food Chemistry, 229, 734-742. doi:10.1016/j.foodchem.2017.02.111

Romero-Cano, L.A., García-Rosero, H., GonzalezGutierrez, L.V., Baldenegro-Pérez, L.A., CarrascoMarín, F. (2017). Functionalized adsorbents prepared from fruit peels: Equilibrium, kinetic and thermodynamic studies for copper adsorption in aqueous solution. Journal of Cleaner Production, 162, 195-204. doi:10.1016/j.jclepro.2017.06.032

Santos, R.M., Neto, W.P.F., Silvério, H.A., Martins, D.F., Dantas, N.O., Pasquini, D. (2013). Cellulose nanocrystals from pineapple leaf, a new approach for the reuse of this agro-waste. Industrial Crops and Products, 50, 707-714. doi:10.1016/j.indcrop.2013.08.049

Selvakumar, P., \& Sivashanmugam, P. (2017). Optimization of lipase production from organic solid waste by anaerobic digestion and its application in biodiesel production. Fuel Processing Technology, 165, 1-8. doi:10.1016/j.fuproc.2017.04.020

Shamsul, N.S., Kamarudin, S.K., Kofli, N.T., Rahman, N.A. (2017). Optimization of bio-methanol production from goat manure in single stage bio-reactor. International Journal of Hydrogen Energy, 42 (14), 9031-9043. doi:10.1016/j.ijhydene.2016.05.228

Shifera, L., Siraj, K., Yifru, A. (2017). Adsorption of lead (II) and chromium (VI) onto activated carbon prepared from pineapple peel: Kinetics and thermodynamic study. Indian Journal of Chemical Technology, 24, 145-152.

Silva, P.A.S. (2016). Transformações na organização produtiva da agricultura camponesa: um estudo da produção de abacaxi de Sergipe. Universidade federal de Sergipe - Programa de Pós-Graduação em Geografia.

Silvestre, M.P.C., Carreira, R.L., Silva, M.R., Corgosinho, F.C., Monteiro, M.R.P., Morais, H.A. (2012). Effect of $\mathrm{pH}$ and Temperature on the Activity of Enzymatic Extracts from Pineapple Peel. Food Bioprocess Technology, 5(5), 1824-1831. doi:10.1007/s11947011-0616-5

Sodtipinta, J., Ieosakulrat, C., Poonyayant, N., Kidkhunthod, P., Chanlek, N., Amornsakchai, T., 
Pakawatpanurut, P. (2017). Interconnected openchannel carbon nanosheets derived from pineapple leaf fiber as a sustainable active material for supercapacitors. Industrial Crops and Products, 104, 13-20. doi:10.1016/j.indcrop.2017.04.015

Solidum, J.N. (2013). Peel wastes of Ananas comosus (L.) Merr., Sandoricum koetjape Merr., Citrus nobilis Lour. as lead and cadmium biosorbent in Manila tap water. Journal of Environmental Science and Management, 16 (2), 28-35.

Spir, L.G., Ataide, J.A., De Lencastre Novaes, L.C., Moriel, P., Mazzola, P.G., De Borba Gurpilhares, D., Tambourgi, E.B. (2015). Application of an aqueous two-phase micellar system to extract bromelain from pineapple (Ananas comosus) peel waste and analysis of bromelain stability in cosmetic formulations. Biotechnology Progress, $31 \quad$ (4), 937-945. doi:10.1002/btpr.2098

Stopar, K. (2016). Presence of nanotechnology in agriculture: bibliometric approach. Acta agriculturae Slovenica, $\quad 107 \quad$ (2), 497-507. doi:10.14720/aas.2016.107.2.20

Tang, P.-L., Hassan, O., Md-Jahim, J., Mustapha, W.A.W., Maskat, M.Y. (2014). Fibrous Agricultural Biomass as a Potential Source for Bioconversion to Vanillic Acid. International Journal of Polymer Science, 2014, 1-8. doi:10.1155/2014/509035

Timofiecsyk, F.D.R., \& Pawlowsky, U. (2000). Minimização de resíduos na indústria de alimentos: revisão. Boletim do Centro de Pesquisa de Processamento de Alimentos, 18 (2), 221-236. doi:10.5380/cep.v18i2.1212

Van Eck, N.J., \& Waltman L. (2018). VOSviewer Manual. Retrieved from http://www.vosviewer.com/gettingstarted
Van Eck, N.J., \& Waltman, L. (2014). Visualizing bibliometric networks. In Ding, R. Rousseau, D. Wolfram (Eds.), Measuring scholarly impact: Methods and practice (pp. 285-320). Springer. doi:10.1007/978-3-319-10377-8_13

Venkateswarulu, T.C., Bodaiah, B., John Babu, D., Venkata Naraya, A., Evangelin, Y. (2015). Bioethanol production by yeast fermentation using pomace waste. Research Journal of Pharmacy and Technology, 8 (7), 841-844. doi:10.5958/0974-360X.2015.00137.7

Wang, Q., Yang, Z., Yang, Y., Long, C., Li, H. (2014). A bibliometric analysis of research on the risk of engineering nanomaterials during 1999-2012. Science of the Total Environment, 473-474, 483-489. doi:10.1016/j.scitotenv.2013.12.066

Yamuna, M., \& Kamaraj, M. (2016). Pineapple peel waste activated carbon as an adsorbent for the effective removal of methylene blue dye from aqueous solution. International Journal of ChemTech Research, 9 (5), 544-550.

Yang, J., Tan, H., Cai, Y. (2016). Characteristics of lactic acid bacteria isolates and their effect on silage fermentation of fruit residues. Journal of Dairy Science, 99 (7), 5325-5334. doi:10.3168/jds.201610952

Zhang, K., Wang, Q., Liang, Q.-M., Chen, H. (2016). A bibliometric analysis of research on carbon tax from 1989 to 2014. Renewable \& Sustainable Energy Reviews, 58, 297-310. doi:10.1016/j.rser.2015.12.089

Zhang, R., El-Mashad, H.M., Hartman, K., Wang, F., Liu, G., Choate, C., Gamble, P. (2007). Characterization of food waste as feedstock for anaerobic digestion. Bioresource Technology, 98 (4), 929-935. doi:10.1016/j.biortech.2006.02.039 